\title{
Nurses' educational practices in Family Health Strategy
}

\author{
Práxis educativa de enfermeiros da Estratégia Saúde da Família \\ Praxis educativa de enfermeros de la Estrategia de Salud Familiar
}

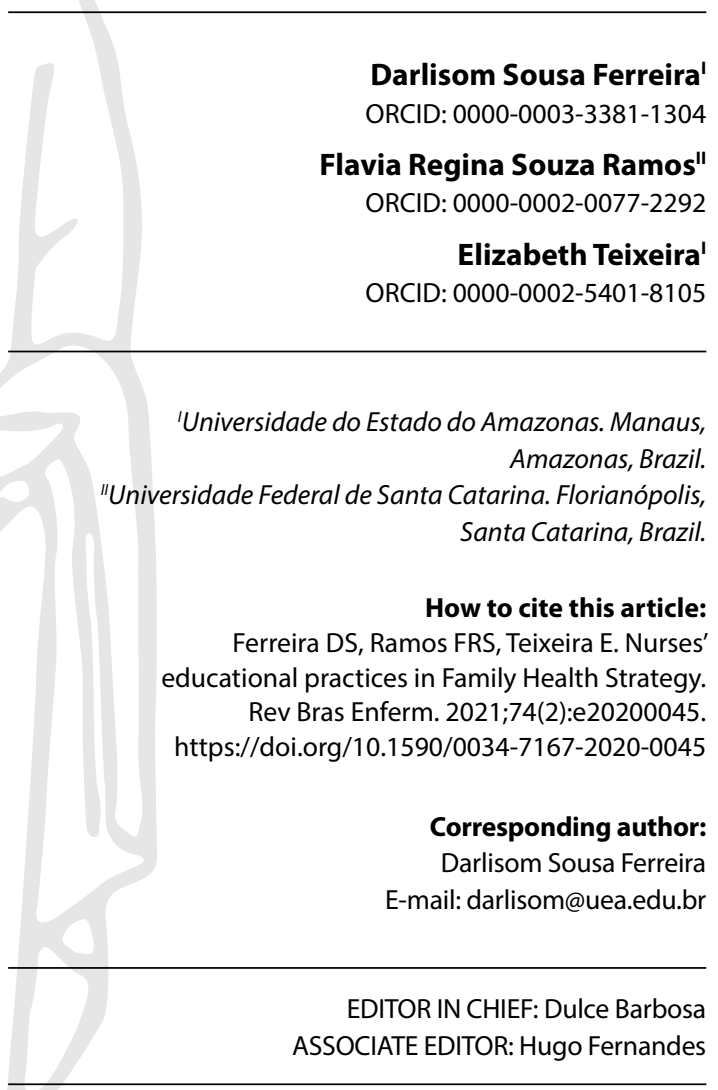

Submission: $04-07-2020$

Approval: 08-22-2020 ABSTRACT
Objectives: to analyze the nurse's educational practice in Family Health Strategy. Methods:
descriptive study with a qualitative approach, whose data production used the World Café
group technique, in two meetings, with 26 nurses of a health district of Manaus-AM. The
technique used was Categorial-Thematic Content Analysis. Results: the study generated two
units of analysis: Political and Organizational Configuration of Educational Work at ESF and
Operational Configuration of Educational Work at ESF, revealing the necessary (re)configurations
in co-management, in the centrality of the subject for the planning of educational work,
and in (re)pactuation between the management of services and training institutions to
overcome contradictions in the implementation of National Policies on Permanent Education
and Basic Health Care. Conclusions: the configuration of nurses'educational practice at ESF
works toward interactions, organized to respond to health policies, incorporating creativity
in doing, but facing numerous obstacles.
Descriptors: Health Education; Family Health Strategy; Family Health Nursing; Primary Health Care; Health Work.

\section{RESUMO}

Objetivos: analisar a práxis educativa de enfermeiros na Estratégia Saúde da Família. Métodos: estudo descritivo com abordagem qualitativa, cuja produção dos dados utilizou a técnica grupal World Café, em dois encontros, com 26 enfermeiros de um distrito de saúde do município de ManausAM. Utilizou-se a técnica de Análise de Conteúdo Categorial-Temática. Resultados: foram geradas duas unidades de análise: Configuração Política e Organizacional do Trabalho Educativo na ESF e Configuração Operativa do Trabalho Educativo na ESF, desvelando necessárias (re)configurações na cogestão, na centralidade do sujeito para o planejamento do trabalho educativo e na (re)pactuação entre a gestão dos serviços e as instituições formadoras para superação das contradições na implementação das Políticas Nacionais de Educação Permanente e de Atenção Básica em Saúde. Conclusões: a práxis educativa dos enfermeiros na ESF se configura em interações, se organiza para responder às políticas de saúde, incorporando a criatividade no fazer, mas enfrentando inúmeros obstáculos. Descritores: Educação em Saúde; Estratégia Saúde da Família; Enfermagem em Saúde da Família; Atenção Primária em Saúde; Trabalho em Saúde.

\section{RESUMEN}

Objetivos: analizar la praxis educativa de enfermeros en la Estrategia de Salud Familiar. Métodos: estudio descriptivo con abordaje cualitativo, para los datos utilizó la técnica grupal World Café, en dos encuentros, con 26 enfermeros de un distrito de salud de ManausAM. Se utilizó la técnica de Análisis de Contenido Categorial Temático. Resultados: han generadas dos unidades de análisis: Configuración Política y Organizacional del Trabajo Educativo y Configuración Operativa del Trabajo Educativo, en la ESF, desvelando necesarias (re)configuraciones de cogestión, centralización del sujeto para planeamiento del trabajo educativo y (re)pactuación entre la gestión de servicios y las instituciones formadoras para superación de las contradicciones en la implementación de Políticas Nacionales de Educación Permanente y Atención Básica en Salud. Conclusiones: la praxis educativa de los enfermeros en la ESF se configura en interacciones, se organiza para responder a las políticas de salud, incorporando la creatividad en el hacer, pero enfrentando innumerables obstáculos. Descriptores: Educación en Salud; Estrategia de Salud Familiar; Enfermería en Salud Familiar; Atención Primaria en Salud; Trabajo en Salud. 


\section{INTRODUCTION}

Although etymologically, the term praxis has the approximate meaning of practice, this manuscript assumes its broadest meaning, controversial and procedural, materialized in the movement of action beyond conduct ${ }^{(1)}$. In this study, praxis is understood as the synthesis between being, thinking, and living in the world, a self-created action based on Marx's work, and taken up again by Paulo Freire in Brazil, as a central problematization - the dialectic union between practice and theory, represented by praxis as the fostering of humanizing processes and revolutionary transformation of social reality ${ }^{(1-2)}$. The specific form of praxis to be approached is the educational praxis materialized in individual and collective manifestations of nurses who act in the Family Health Strategy (ESF) ${ }^{(1)}$.

The ESF was born in Brazil in 1994, formulated by the Ministry of Health $(\mathrm{MH})$ and launched under the name of the Family Health Program (PSF), a program of Primary Health Care (APS) that sought to differentiate itself from the model previously under development. In 1997, it started to be defined as a strategy because it was not only a "program" but a policy with organizational and substitute character, facing the traditional model of primary care ${ }^{(1)}$. Therefore, it is part of the health sector reform process, supported by the Federal Constitution, aiming at increasing accessibility to the health system and increasing actions on prevention and health promotion ${ }^{(1,3)}$.

The advances produced by ESF in the political-institutional, organizational, and technical-assistance dimensions are undeniable. The former observed an expansion of primary care, institutionalization, promotion of equity, intersectoriality, and confrontation of personnel management issues training and education for the health system. The integration of the services network, planning, and social participation is highlighted in the organizational dimension. In the technical-assistance dimension, there are benefits to multidisciplinary work, family focus, shelter, bonding, humanization, and production of care $\mathrm{e}^{(1,4)}$.

The educational practice linked to the actions of APS seeks to overcome the dichotomization of teaching care. Studies conducted in the last two decades ${ }^{(1,5-6)}$ have pointed out the nurses' educational praxis at ESF in a positive way for teamwork, because it bestows, based on the praxis itself, the cast of educational priorities and the recognition of the subjects' needs, making from there emerge the ends that direct the proposal of work to be developed by the team with the population ${ }^{(1)}$.

Studies that discuss the health work process in the scope of the Family Health Strategy indicate that one of the challenges is the production of other models that promote the confrontation of contradictions and difficulties, the implementation of ruptures, and the adoption of different postures, in order to seek for options and possibilities of creation ${ }^{(1,7)}$. Given the above, it is necessary to carry out studies that analyze the educational praxis in ESF, in order to subsidize the collective construction of paths and new ways of doing education in health services. The reflection in real work contexts and through participative dialogue presupposes that ESF professionals are actors in subjectivating praxis. It is not a matter of interpreting the good or bad practice in progress, but of unveiling possible paths of pertinent knowledge $\mathrm{e}^{(1)}$. The guiding question was: How is a nurses' educational practice of Family Health Strategy in a health district of Manaus-AM $?^{(1)}$

\section{OBJECTIVES}

To analyze the nurses' educational practice of the Family Health Strategy, in the Health District East of Manaus-AM'1.

\section{METHODS}

\section{Ethical aspects}

This research is a model of a project entitled "Construction and validation of instruments for nurses' educational praxis in Family Health Strategy." They based the project upon ethical principles of Resolutions 466/2012, 510/2016, and 580/2018 of the National Health Council (CNS), which govern research with human beings, social sciences, and strategic interest within the Unified Health System (SUS). It received institutional consent from SEMSA, was submitted to the Brazil Platform, and obtained an opinion consubstantiated of approval by the Research Ethics Committee of a University on November 10, 2017 ${ }^{(1)}$. The Free and Informed Consent Term and the Authorization Term for the use of Image and Voice were signed.

\section{Approach and type of study}

The option for the qualitative approach gave the contextual, dialectical, constructivist critical character in which the understanding of the object emerges from the constructions, produces intervention effects, and incorporates, based on the social relations of the participants, the question of the meaning of necessary actions and the intentionality as inherent to the acts, relationships, and social structures. They took the latter as significant human construction, both in their advent and transformation, proposing alternatives, in the search for solutions, and the very ethical-political positioning of the research ${ }^{(1,8-9)}$.

This type of study participant allows to know one's own reality, participate in the production of knowledge, and learn to write and rewrite one's own history. The researcher is like someone who helps and serves as a tool of scientific knowledge. Researchers and participants work together, even if in different situations and tasks ${ }^{(1,10)}$

\section{Methodological procedures}

\section{Study scenario}

The research scenario was the District of Health Leste (DISAL) of the Municipal Health Secretariat (SEMSA), in a city of Manaus, capital of Amazonas. With coverage of $51.68 \%$ of the population, Basic Care is organized in five Health Districts (four urban and one rural), with 305 health care establishments (EAS), of which 215 are Basic Health Units (UBS). ESF has 225 teams and reaches $32 \%$ coverage, and DISAL has 58 ESF teams with 37 active nurses ${ }^{(1)}$.

\section{Data source, inclusion, and exclusion criteria}

Twenty-six nurses from Basic Family Health Units (UBSF) participated in the study, included by the following criteria: to be an effective SEMSA professional and to have a minimum of two 
years in this service. The research excluded nurses on leave in health treatment, premium leave, maternity leave, or any other type of leave during the data gathering period ${ }^{(1)}$.

\section{Data gathering, organization and analysis}

The data gathering took place between June and August 2018. The group technique called World Cafe Method was used in two meetings, with 12 and 14 participants. This technique works as a meeting of people who, through meaningful and strategic conversations, seek meaning for the multiple contexts in which they live, work, or have fun. There, the conversations favor the discovery and participatory construction of joint solutions to collective problems ${ }^{(1,11)}$. The technique was coordinated by the "host-researcher," who made the study participants raise awareness through telephone contact followed by visitations to the UBSFs of DISAL.

The group technique used a space, located in a central district of the city, called "Café com Texto," which was reserved exclusively for the study on the days and times agreed with the participants. At the World Café meetings, participants were organized in groups of four people per table, one of whom was chosen by the group as "table hostess." The tables contained paper towels, crayons, and various pens for scribbling, taking notes, or recording ideas ${ }^{(1)}$. The dialogues' starting question was: What can Family Health Strategy teams create to enhance educational practice in health?

The dialogues took place in 15-minute rounds, after which the participants exchanged tables to talk with another group. In the last round, people returned to their initial tables to synthesize the discussions, discoveries, and organize and share each group's ideas, in a moment of manifestation of collective knowledge. The meetings lasted three hours and were filmed and photographed. The research relied on trained research assistants for logistics, records, and other aspects of infrastructure ${ }^{(1)}$.

In the organization and processing of data, the contents of the tablecloths and videos were transcribed and processed with the help of Atlas.ti 8 (Qualitative Research and Solutions), version 8.3.20/2019, a CAQDAS (Computer Assisted Qualitative Data Analysis Software) that has been widely used in the most diverse areas of research ${ }^{(1,12)}$. It is a technological resource that allows different types of textual and image data analysis, articulating different theoretical-methodological approaches, facilitating the management in the organization process of a large amount of data, and contributing to the accuracy and scientificity in the interpretation of meanings. For analysis, this software's use was combined with Thematic Categorical Content Analysis ${ }^{(1,13)}$ to understand the discourses and their meanings. The steps of the analysis were: 1 . floating reading of the corpus of analysis; 2 . definition of the units of record (discursive expressions); 3 . thematic grouping into units of meaning; 4 . definition and naming of subcategories and categories; 5 . magnitude/quantification of segments; 6 . association of categories to scientific knowledge.

The transcribed discursive data were treated in a Hermeneutic Unit (UH) with two Primary Documents (PD), one for each World Coffee held. The documents generated ten Research Codes (RC) in the selective coding process, related to 189 segments of discursive expressions grouped by meaning. In the process of axial coding by association and interpretation, they generated two sets (Code Groups), here called Units of Analysis (UA) ${ }^{(1)}$.

\section{RESULTS}

Of the ten research codes, five formed the Analysis Unit called "Political and Organizational Configuration of Educational Work in ESF," and five codes constituted the Unit "Modes of Doing Educational Work in ESF." Chart 1 presents each Analysis Unit, its respective codes, indicating their magnitude according to the number of discursive segments that compose them ${ }^{(1)}$.

Chart 1 - Units of Analysis of the educational praxis of nurses at ESF Manaus, 2019

\begin{tabular}{|c|c|c|c|}
\hline $\begin{array}{l}\text { UH/ } \\
\text { DP }\end{array}$ & RESEARCH CODES - RC & $\begin{array}{c}\text { UNITS OF } \\
\text { ANALYSIS - UA }\end{array}$ & Magnitude \\
\hline \multirow{2}{*}{$\begin{array}{l}1 \mathrm{UH} / \\
2 \mathrm{DPs}\end{array}$} & $\begin{array}{l}\text { 1. Cogestion and community } \\
\text { ties } \\
\text { 2. Educational demands } \\
\text { motivated by community } \\
\text { actors } \\
\text { 3. Contribution of other } \\
\text { partner actors } \\
\text { 4. Productivist work process } \\
\text { 5. Partnerships and } \\
\text { intersectorality }\end{array}$ & $\begin{array}{l}\text { Political and } \\
\text { Organizational } \\
\text { Configuration } \\
\text { of Educational } \\
\text { Work at ESF } \\
\text { (CPO-TESF) }\end{array}$ & $\begin{array}{c}83 \\
\text { Segments }\end{array}$ \\
\hline & $\begin{array}{l}\text { 6. Outpatient individual } \\
\text { educational work } \\
\text { 7. Group educational work by } \\
\text { health condition } \\
\text { 8. Momentary educational } \\
\text { work } \\
\text { 9. Methodological strategies } \\
\text { and resources of } \\
\text { educational work at the ESF } \\
\text { 10. Permanent education for } \\
\text { the ESF }\end{array}$ & $\begin{array}{l}\text { Operational } \\
\text { Configuration } \\
\text { of Educational } \\
\text { Work at ESF } \\
\text { (COP-TESF) }\end{array}$ & $\begin{array}{c}106 \\
\text { Segments }\end{array}$ \\
\hline
\end{tabular}

Note: UH - Hermeneutic Unit; DP - Primary Documents; ESF - Family Health Strategy. Source: World Café - Corpus of Video Transcriptions and Tablecloths.

In the first Analysis Unit (Political and Organizational Configuration of Educational Work at ESF), five research codes reveal elements directly linked to the premises of the Unified Health System regarding the work with the community, its motivations and needs of knowledge, as well as the ongoing intersectoral partnerships and others necessary for the effectiveness of educational work. This code includes elements related to political and community relations, organization, social control, and management of the nurse's educational work process ${ }^{(1)}$.

Research code 1 highlights co-management and community ties as fundamental subsidies for teamwork, expressing that the organization of educational work needs to be supported by the community $^{(1)}$.

We need the interaction of community leaders to have this support and be able to improve our work. We will know the most significant need that we have within our community, and with the support of leadership, maybe we can do much more than we do. (Enf1)

The educational demands motivated by the community actors constitute the elements of the research code 2 , which reveals the inclusive perspective and social participation of the community 
as necessary in the planning of the actions to be developed with the users ${ }^{(1)}$.

We put the motivation, the one in which the community presented demand to us, so that we could arm ourselves and pass on information about that demand that arose. Then, the team must be motivated to develop those themes the community demanded. (Enf4)

The elements of research code 3 express the recognition of the contribution of partner actors in the development of educational work, involving schools, churches, non-governmental organizations (NGOs) located in different territories ${ }^{(1)}$.

Another thing that could be helpful is training. Making the team between the health team and the education team, that is, that school where you work, could form a little group, a team could take care of a part: do recreations for children, adolescents, be helping in this issue of health education. This school we are talking about is a linked school. (Enf2)

So, my reality is different, I have a partnership with the school, I have the church next to the unit, I have the full-time school in front of us, which has a participative program, that invites us to participate with them in the lectures, there are four more schools, our team is good in the interaction with the schools, we have two NGOs also that looked for us seeking help. (Enf3)

In research code 4, are pointed out a productivist work process, the problems arising from work regulated and measured by strictly quantitative metrics and daily targets or volume of services, in a productivist regime not very sensitive (disconnected) to specific realities and actors. Most of the ESF nurse's work time is dedicated to assistance activities or bureaucratic controls around his work, to detriment of educational actions with the community and the team members themselves ${ }^{(1)}$.

The system alienates us. Everything is the system because I have to generate a number, stop doing good assistance, stop promoting health. After all, the system's quantity alienates the health promotion. (Enf5)

Another thing is the quality of attendance because we do not have the quality in attendance; they ask for a quantity and not quality, which already harms our work a lot. (Enf6)

But then I tell you, am I going to form groups for the team's permanent education if I do not have time to promote health education? I have to find time to promote team education too, if you, nurse, alone want to do everything, you cannot. (Enf7)

The strategy nurse is very stuck in the assistance; he is too focused on bureaucracy, demand that takes much time. (Enf8)

The research code 5 brings elements that reveal the need for advances in partnership and intersectorality with the potential to transform the conceptions and practices of the ESF team. In this code, some elements reveal the search for knowledge from the university's permanent relationship and the health service in the preparation and technical and scientific enrichment of ESF professionals. Thus, it has a close relationship with permanent education, highlighted here as a political guideline with impacts on the organization of work ${ }^{(1)}$.

Universities Professionals inside the health units change a conception and work very well; there is such an increase of knowledge for the health units, much improvement within this health team. So, it would be particularly useful if we could establish permanent partnerships. (Enf24)

Universities Professionals inside the health units change a conception and work very well; there is such an increase of knowledge for the health units, much improvement within this health team. So, it would be particularly useful if we could establish permanent partnerships. (Enf25)

In the second Analysis Unit, entitled "Operational Configuration of Educational Work in ESF," the discursive elements describe the models used in health education developed in ESF, innovative strategies and technologies, as well as the need for continuous education ${ }^{(1)}$.

The first three research codes of this UA $(6,7,8)$ express tendencies or models of making that coexist and interact in the educational activity with the users - individual actions, group actions, and a third assumed as remaining practices of old nurse actions. There is a restriction in individual ambulatory educational work (code 6), development of orientations, linked to consultations, and programmatic actions, such as passing on information the professional considers necessary for that service ${ }^{(1)}$.

The path for Health education is individual; yes, it is daily, if you do that every day. (Enf9)

When I attend the patient, I already have a daily list of guidelines to give him. According to the needs of each patient who requires that orientation, I will spend a little more time with him. (Enf10)

I do not think I can do it like I used to, because now I need to fulfill goals, I have a time practically determined for each patient. (Enf1)

According to a health condition (research code 7), group educational work is as an eventual alternative of educational action through lectures directed to users' segments by health condition. To execute the units, size and physical structure must be available for the development of this practice ${ }^{(1)}$.

As the unit's service is also no longer per population group, per program, this [reality] deconstructs, because we end up not having time; and time is everything, even to give a lecture. There is a collective activity, but collective activity is a part of it, you speak here, everybody signs, and it is over. (Enf12)

With one pregnant woman, it is one thing. It is another with an older man, but now I cannot work with groups anymore like l used to do. Today I work only with the group of pregnant women. (Enf13)

In our reality, we have the little house, the house, mine is strategy, where we have three teams, so everything is a different reality. In mine, thank God, I can innovate, because our structure is big, our area is big, and l enjoy the time they are doing the screening process. (Enf14) 
The short educational work (research code 8) is that carried out without planning, without recognizing the needs of the subjects, the desire to know, at the reception, in the waiting room, minutes before the medical care, recognized as "of old."The reports show hegemonic practices that conceive health education as a strategy of normative, prescriptive, and passive behavioral modeling ${ }^{(1)}$.

Honestly, this old-fashioned thing... Ah! I schedule with the women at a school, call and go where they live, you are going to give a lecture for these women about breast cancer, people! They will not go, they will not go, just a few hangdogs appear. So, what is the opportunity? It is that moment when they are there waiting for the consultation, only they are waiting for the consultation wanting to leave too. I say: "Doctor, wait 10 minutes before calling them and I will make a quick conversation here about breast cancer". She holds the consultation. Then they start complaining: "Doctor, aren't you going to call our names?" You are talking [about the issue]and they are complaining, "The doctor will not attend us today?" (Enf15)

The methodological strategies and resources of the educational work at ESF (research code 9) focus on a set of technologies used by nurses at ESF, ranging from traditional (expository) to more spontaneous and emerging adaptations and creations (dialogical), including the use of mobile devices ${ }^{(1)}$.

The rounds of conversation are an excellent strategy and form a better bond. The conversation circle presents the specialties, unlike the waiting room, which includes everything. I will work the demands, because we think we know it all, speak briefly, and those who know nothing learn even less. (Enf20)

We make a quarterly certificate of recognition, man, woman, adolescent [...] and we did a workshop to build puppets, we stay in the unit to use in lectures. (Enf21)

Every team has WhatsApp groups. We have one day to work on continuing education; who does not have a smartphone today? And so, we get fed up with information all day by WhatsApp. (Enf22)

So, we also formed a WhatsApp group [with users], and it worked. We also have a group of vulnerable families. (Enf23)

The research code number 10 highlights the need for permanent education at ESF, with a view to the search for knowledge, skills, and attitudes necessary to achieve mechanisms that qualify the educational work at ESF(1).

The professional should seek knowledge in order to develop a mechanism to reach the user in the practices of health education. (Enf16)

Many times, professionals do not know where to look for working methodologies, like searching in a database, a book that will improve the practices within the services. (Enf17)

The assistance void does not allow you to develop the practice of health education, we cannot do it if we do not have our base. (Enf18)

So, I observed, and the team is used to, accommodated with, "everything has to be the nurse" and "I will not do it because I do not know how to do it." Training together so that everyone, who guides in the same language, to use accessible language. (Enf19)

\section{DISCUSSION}

In the configuration of the educational practice of nurses at ESF, from the First Unit of Analysis, emerged political and organizational configurations that directly impact service users of the educational work ${ }^{(1)}$.

The co-management and link with the community are tools to support and improve the professional do. To co-manage the studied scenario is not to be an "operationalized" subject by the system, but an "operationalizing" actor of the process, the one who, through participation, becomes the operator of its needs, difficulties, desires, knowledge, and powers in the construction of educational work in health ${ }^{(1)}$.

The current perspectives of co-management are materialized by participation and collective construction devices, since they grant responsibility to all social actors involved (workers, managers, and users), who start participating in the unit planning and organization, intervening in the improvement of work processes and health production quality in Primary Care ${ }^{(1,14)}$. The study nurses highlighted the imperative need for resuming interaction with community leaders in the search for solutions to the challenges, dilemmas, and perspectives of educational work in health.

Since the 8th National Health Conference (CNS), the assistance model's reorientation has its proposal based on the participation movement as a mechanism for building and consolidating SUS. However, this reorientation has brought us numerous challenges, and in the scope of the ESF, educational work is an essential part of the integral and continuous attention to families in the areas assigned to the program ${ }^{(1)}$.

The policies materialize services and concerning community involvement in the construction and co-management of SUS, guaranteeing user's participation in Law 8.142/90. Since the creation of Conferences and Health Councils $s^{(1,14)}$, the demands of social movements and their communities constitute the guidelines that integrate the planning of actions required to the territories and their players.

Although co-management means thinking and creating collectively ${ }^{(1,15)}$, representative participation and the actors' contribution to the territory has not been a reality for all nurses. Some territories have fully institutionalized the contribution of partner actors, such as schools, churches, associations, and non-governmental organizations; others are incipient in the articulation-collaboration, which reveals an urgent need for the establishment of intersectoral partnerships for the (re)configuration of political and organizational educational work in their teams and territories ${ }^{(1)}$.

As a political and organizational configuration, the actors and the community's educational demands need to consolidate a strategy and response to individual and local needs and specificities. Those actions would transform political-organizational decisions and referrals into instruments for meeting the population desires, beyond the programmatic limitations and the real requirements of the ESF teams $s^{(1)}$.

The nurse who works at ESF, in general, makes home visits, performs nursing consultations, meets spontaneous demand, 
performs private procedures, besides developing the managerial function ${ }^{(1,16)}$, an inseparable singularity of nursing work, but which is still a product of incomprehension and has repercussions in the technical division of work ${ }^{(1,17)}$.

Nurses associated the process of productive work to bureaucracy, work overload, spending too much time on programmatic activities, assistance/education dichotomy, and achievement of quantitative goals, which have been creating alienation to the system, mishaps in the maintenance of teamwork ${ }^{(1,18)}$ and lack of knowledge of the nursing work itself.

Nursing is the only health profession with an increasing proportion of work hours, greater than or equal to 40 hours per week $^{(1,19)}$. The Nursing Professional Exercise Law regulates that educational work is an inherent activity of the nursing profession and aims at improving the health of the individual, the family, and the population in general. It is necessary to review the ordering of educational work in ESF fragmented by the metric-assistencialist focus ${ }^{(1,20)}$, of action far from those recommended to solve problems in a harmonic relationship between the workload and the activities developed by nurses in $\mathrm{ESF}^{(1)}$.

The process of productivist work, of mechanized scope, generates damages to the policies, the professionals, and the users' lives. Even nurses connect to the assistance activities, and the educational work cannot diverge and neglect ESF's daily actions. It is necessary to build understandings that will associate caring with educational activities, in an articulated proposal of preservation of the precepts of the National Policy for Health Promotion (PNPS) for a reorientation of the model of attention (and education) to health $^{(1)}$.This integration of the educational-cautious doing goes through the fragile, pedagogical preparation, whose theoreticalpractical instrument enhances the educational activities in all instances, whether they are assistential or managerial. Meanwhile, pedagogical qualification promotes professionals confrontation and empowerment through a dynamic, dialogical, and political process, which develops through reflection and dialogue among subjects, resulting in a commitment to change reality ${ }^{(1,21)}$.

Considering that the discussion on health promotion has been strengthened in the global scenario presenting proposals for a redefinition of public policies, directing another look to the health context. Understand that biomedical devices are not capable of modifying social determinants and conditioning of the health-disease process ${ }^{(1,21)}$, partnerships and intersectoriality revealed in the participants discourse the perspective to expand public policies. Through the intersectoriality in an integrated search for actions and services in a non-fragmented manner ${ }^{(1,22)}$ to strengthen and increase health services or other spaces, such as squares, schools, community territories, NGOs, industries, among others. However, the concept of intersectoriality that permeates the study is taken as problematic, since it does not translate professional and/or management strategy, but rather interprofessional arrangements by nurses and their teams ${ }^{(1)}$.

The partnership and intersectoriality materialize in the teachingservice articulation, which is transversal to two analysis units: first, as a partner for the educational competence development ${ }^{(1,23)}$ of ESF nurses; and second, as a strategy for continuing education in $\mathrm{ESF}^{(1,24)}$. These processes broaden horizons, (de)naturalizing obsolete practices and trainers of sensitive and committed subjects-workers in the construction of practices that do not only constitute biomedical knowledge $\mathrm{e}^{(1,25)}$.

The individual educational work is carried out in nursing consultations from a list of informative "orientations" according to goal and/or programmatic action. These conducts ratify the maintenance of the authoritarian hegemonic model ${ }^{(1,26)}$ and disregard the determinants and their multiple influences in the health-disease process.

In group educational work by a health condition, the population groups organized actions according to pathology or program. The lecture is the strategy that remains operational, persisting in the conception that marginalizes the students' needs and their experiences in the centrality of the process of knowledge construction ${ }^{(1,26)}$. However, the emergence of advances in educational work is perceived, through the use of pedagogical processes and techniques based on the collective, centered on the socialization of life, developed based on daily experiences, assuming the group dialogue as the construction of liberation and transformation of problems into health solutions ${ }^{(1)}$.

The lecture is maintained as a resource to help the lack of information and guidance in the clinical care of multi-professional work in health ${ }^{(1,27)}$; it is useful when in conjunction with educational programs. In the study scenario, the lecture's use was portrayed as an old strategy, with little adherence, although still opportune, mainly when waiting for the medical consultation, being configured as a short educational work ${ }^{(1)}$. Thus, the importance of training nurses to act as educators is perceived, in a critical, progressive, and transforming perspective ${ }^{(1,28)}$ of daily practice at ESF.

The recognition of a specific community's educational needs is not fully used as a participatory planning tool nor listed as a priority. Joining co-management and ongoing health education are synonymous with transforming the daily practices of SUS ${ }^{(1)}$ workers. From this perspective, the Freirean (Paulo Freire's) legacy, committed to its "what to do" - being available for dialogue, common sense, humility, freedom, joy and hope, respect for human beings, ethics, aesthetics, and the conviction that change is possible - becomes a possibility for overcoming the limitations of educational practice at the $\operatorname{ESF}^{(1,29-30)}$.

Regarding the methodological strategies and resources of the educational work at ESF, the conversation circle highlighted an alternative for bond formation and recognition of the subjects' demands; and it has been widely used by nursing ${ }^{(1,31)}$ for being an active, critical, reflective educational methodology that deepens the dialogue, stimulates democratic participation and effectively contributes to the promotion of the population's health ${ }^{(1)}$.

Although there are no Information and Communication Technologies (ICT) at the UBSF, the mobile application WhatsApp was incorporated, taking ESF teams educational. ICTs, in the public health and cyberculture interface ${ }^{(1,32)}$, is still little explored in the preparation/execution of educational work at $\operatorname{ESF}^{(1,33)}$, but, although incipient, the reality studied innovates with the use of this tool to support the management of the unit ${ }^{(1,34)}$ and to promote the health of vulnerable communities ${ }^{(1,35)}$, creating means to integrate people, with low-cost technologies and the broad access ${ }^{(1)}$.

The National Policy for Permanent Education needs to strengthen a qualifying strategy for health professionals. Study 
participants emphasize and recognize the need for improvement and preparation for action in the face of countless challenges, and place pedagogical knowledge as a preponderant element for transforming educational actions $s^{(1,36)}$.

The teaching-service articulation ${ }^{(24)}$ emerges as a fundamental element of continuing education for ESF. However, there is a need for adjustments among workers' demands to public policies and a (re)pactuation among service management and training institutions, aiming at overcoming contradictions in the implementation of the National Policy on Permanent Education in Health ${ }^{(1)}$.

\section{Study limitations}

Among the limitations of this study, it is worth mentioning the restrictions to the scenario studied, limiting generalizations of the findings to other Family Health Strategy teams from other contexts. However, some issues and characteristics discussed associate us with a practice peculiar to interprofessional and teamwork, which places this research scenario potentially similar to others. Future studies include the other categories/members that integrate ESF in different regions of Brazil.

\section{Contributions to Nursing, Health or Public Policy areas}

The results of this study filled a scientific gap in the reviewed context by discussing with originality the educational praxis as an alternative of knowledge intervention and production in health; and by highlighting the work and creativity of the nurse in the translation of public health policies, even if intertwined by numerous obstacles. In this sense, it contributes substantially to the discussion on the nurse's educational work planning, revealing political, organizational, and operative configurations pertinent and applicable to other scenarios and units of the same typology in the context of Primary Health Care in Brazil.

\section{CONCLUSIONS}

The study achieved its objective since it analyzed the educational practice of nurses in the ESF of the Eastern Health District of Manaus, revealing a delicate balance. The educational practice proved to be transforming of iniquities and a possible alternative to other modes of knowledge-intervention and production in health. It is necessary to look at the present moment and face the challenges with alternatives that consider professionals and users as subjects of production/transformation of the educational praxis in $\mathrm{ESF}^{(1)}$.

Ways of doing educational work include using strategies and pedagogical techniques to socialize knowledge, share knowledge, and train health professionals in life care. Both authoritarian and coercive practices were verified, which do not consider the psychosocial and cultural determinants of behavior. Criticalreflexive, liberating, and constructing new knowledge practices are ratified - in an oscillating, intermittent between hegemonic and dialogic models of education ${ }^{(1)}$.

The nurse's work is configured in interaction, responds to the political bases of health, incorporates creativity in doing, but encounters numerous obstacles. There is a movement "from the past" to the "present"; there are tensions and intentions; hermeticism and fractures ${ }^{(1)}$.

\section{REFERENCES}

1. Ferreira DS, Ramos, FRS. Práxis educativa de enfermeiros na estratégia saúde da família: do real conceptualizado à inovação tecnológica [Tese] [Internet]. 2021 [cited 2019 Aug 20]. Available from: https://repositorio.ufsc.br/handle/123456789/211685

2. Pereira DA, Rocha SFM, Chaves PM. O conceito de práxis e a formação docente como ciência da educação. Rev Ciênc Hum [Internet]. 2016[cited 2017 May 29];17(29):31-45. Available from: http://revistas.fw.uri.br/index.php/revistadech/article/view/2307/2182

3. Pinto LF, Giovanella L. Do Programa à Estratégia Saúde da Família: expansão do acesso e redução das internações por condições sensíveis à atenção básica (ICSAB). Ciênc Saúde Colet. 2018;23(6):1903-14. https://doi.org/10.1590/1413-81232018236.0559201

4. Arantes LJ, Shimizu HE, Merchán-Hamann E. Contribuições e desafios da Estratégia Saúde da Família na Atenção Primária à Saúde no Brasil: revisão de literatura. Ciênc Saúde Colet. 2016;21(5):1499-509. https://doi.org/10.1590/1413-81232015215.19602015

5. Ramos FRS. O Processo de Trabalho de Educação em Saúde. In: Ramos FRS, Verdi MM, Kleba ME. Para Pensar o Cotidiano: educação em saúde e a práxis da enfermagem. Florianópolis: UFSC; 1999. p. 16-61.

6. Roecker S, Nunes EFPA, Marcon SS. O trabalho educativo do enfermeiro na Estratégia Saúde da Família. Texto Contexto Enferm. 2013;22(1):157-65. https://doi.org/10.1590/S0080-62342012000300016

7. Ribeiro EM, Pires D, Blank VLG. A teorização sobre processo de trabalho em saúde como instrumental para análise do trabalho no Programa Saúde da Família. Cad Saúde Pública[Internet]. 2004 [cited 2017 May 29];20(2):438-46. Available from: http://www.scielo.br/pdf/csp/v20n2/11.pdf

8. Prado ML, Souza ML, Monticelli M, Cometto MC, Gómez PF. Investigación cualitativa en enfermería: metodología y didáctica. Washington (DC): Organización Panamericana de la Salud; 2013.

9. Witt T, Gianotten V. Investigación participative en un context de economia campesina. In: Monroy GV. La investigación participativa en América Latina: antología. Pátzcuaro, Michoacán: CREFAL; 1983. p. 225-78.

10. Brandão CR, Streck DR. Pesquisa Participante: o saber da partilha. São Paulo: Saraiva; 2006.

11. Brown J, David I. O World Café: dando forma ao nosso futuro por meio de conversações significativas e estratégicas. São Paulo: Cultrix; 2007.

12. Forte ECN, Pires DEP, Trigo SVVP, Martins MMFPS. A hermenêutica e o software ATLAS.TI: união promissora. Texto Contexto Enferm. 2017;26(4):e0350017. https://doi.org/10.1590/0104-07072017000350017 
13. Bardin L. Análise de conteúdo - Ed. Revista e Ampliada. São Paulo: Edições 70;2011.

14. Conselho Nacional de Secretários de Saúde (BR). Coleção para entender a gestão do SUS: Sistema Único de Saúde. v. 1. Brasília, DF: CONASS; 2011.

15. Ministério da Saúde (BR). HumanizaSUS: gestão participativa: cogestão. 2. ed. Brasília: MS; 2009.

16. Trindade AA, Resende MA, Souza G, Dias RA, Calsavara RA, Franco AC, et al. As implicações práticas do enfermeiro em saúde da família: um olhar sobre a sala de imunizações. REAS. 2019;(19):e263. https://doi.org/10.25248/reas.e263.2019

17. Leal JAL, Melo CMM. The nurses' work process in different countries: an integrative review. Rev Bras Enferm. 2018;71 (2):413-23. https://doi. org/10.1590/0034-7167-2016-0468

18. Peruzzo HE, Bega AG, Lopes APAT, Haddad MCFL, Peres AM, Marcon SS. Os desafios de se trabalhar em equipe na estratégia saúde da família. Esc Anna Nery. 2018;22(4):e20170372. https://doi.org/10.1590/2177-9465-ean-2017-0372

19. Oliveira BLCA, Silva AM, Lima SF. Carga semanal de trabalho para enfermeiros no Brasil: desafios ao exercício da profissão. Trab Educ Saúde. 2018;16(3):1221-36. https://doi.org/10.1590/1981-7746-sol00159

20. Nascimento AG, Cordeiro JC. Núcleo ampliado de saúde da família e atenção básica: análise do processo de trabalho. Trab Educ Saúde. 2019;17(2):e0019424. https://doi.org/10.1590/1981-7746-sol00194

21. Pinto MB, Silva KL. Promoção da saúde no território: potências e desafios dos projetos locais. Esc Anna Nery. 2019;23(1):e20180282. https:// doi.org/10.1590/2177-9465-ean-2018-0282

22. Costa RE, Medeiros AK. Cooperação e Intersetorialidade na Política sobre drogas no Brasil. RASI 2019;5(1):21-40. https://doi.org/10.20401/ rasi.5.1.255

23. Leonello VM, Vieira MPM, Duarte TCR. Competencies for educational actions of Family Health Strategy nurses. Rev Bras Enferm. 2018;71(3):1072-8. https://doi.org/10.1590/0034-7167-2017-0390

24. Schott M. Articulação ensino-serviço: estratégia para formação e educação permanente em saúde. REFACS 2018;6(2):264-8. https://doi. org/10.18554/refacs.v6i2.2825

25. Lopes MCR, Morel CM. Processos de aprendizagem de adultos na educação profissional em saúde. Trab Educ Saúde. 2019;17(1):e0018111. https://doi.org/10.1590/1981-7746-sol00181

26. Almeida ER, Moutinho CB, Leite MTS. Prática pedagógica de enfermeiros de Saúde da Família no desenvolvimento da Educação em Saúde. Interface (Botucatu). 2016;20(57):389-402. https://doi.org/10.1590/1807-57622015.0128

27. Ferreira DL, Resende EAMR, Lucas ALR, Silva ACF, Lenci SS, Silva SGF, et al. O efeito das equipes multiprofissionais em saúde no Brasil em atividades de cuidado com o diabetes. REAS. 2019;(17). https://doi.org/10.25248/reas.e91.2019

28. Saboia VM, Valente GSC. A prática educativa em saúde nas consultas de enfermagem e nos encontros com grupos. Rev Enf Ref [Internet]. 2010[cited 2019 Aug 09];serllI(2):17-26. Available from: http://www.scielo.mec.pt/pdf/ref/vserllln2/serllln2a02.pdf

29. Silva KL, Barcelos BJ, França BD, Araújo FL, Magalhães NTI, Ledo MM. Entre experimentações e experiências: desafios para o ensino das competências para a promoção da saúde na formação do enfermeiro. Interface (Botucatu). 2018;22(67):1209-20. https://doi.org/10.1590/1807-57622017.0467

30. Freire P. Pedagogia do Oprimido. 50 ed. São Paulo: Paz e Terra;2011.

31. Dias ESM, Rodrigues ILA, Miranda HR, Corrêa JA. Roda de conversa como estratégia de educação em saúde para a enfermagem. Rev Pesqui: Cuid Fundam. 2018;10(2):379-84. https://doi.org/10.9789/2175-5361.2018.v10i2.379-384

32. Honorato EJ, SantAna. A interface entre Saúde Pública e Cibercultura. Ciênc Saúde Colet. 2014;19(2):481-5. https://doi. org/10.1590/1413-81232014192.21512012

33. Mota DN, Torres RAM, Guimarães JMX, Marinho MNASB, Araújo AF. Tecnologias da informação e comunicação: influências no trabalho da estratégia Saúde da Família. J Health Inform [Internet] 2019 [cited 2019 May 29];10(2):45-9. Available from: http://www.jhi-sbis.saude.ws/ ojs-jhi/index.php/jhi-sbis/article/viewFile/563/330

34. Pinto LF, Rocha CMF. Inovações na Atenção Primária em Saúde: o uso de ferramentas de tecnologia de comunicação e informação para apoio à gestão local. Ciênc Saúde Colet. 2016;21(5):1433-48. https://doi.org/10.1590/1413-81232015215.26662015

35. Oliveira EF, Jesus VS, Siqueira SMC, Alves TA, Santos IM, Camargo CL. Promovendo saúde em comunidades vulneráveis: tecnologias sociais na redução da pobreza e desenvolvimento sustentável. Rev Gaúcha Enferm. 2015;36:200-6. https://doi.org/10.1590/1983-1447.2015. esp.56705

36. Menegaz JC, Backes VMS, Zamprogna KM, Lima MM, Costa TP. Obstáculos para o encontro pedagógico entre professores e estudantes de enfermagem em diferentes contextos educacionais. Educ Pesqui. 2018;44:e176325. https://doi.org/10.1590/s1678-4634201844176325 